岡山医誌（1993） 105，63～72

\title{
血液・膝関節液中の因子測定值による 慢性関節りウマチと 変形性膝関節症の比較と判別分析
}

岡山大学医学部整形外科学教室（指遒：井上一教授）

宗友和生

(平成 4 年11月 13 日受稿)

Key words：慢性関節リウマチ，判別分析，リウマチ因子，C一反応性蛋白， $\beta_{2}$ マイクログロブリン

\section{粕言}

慢性関節リウマチ（以下 RA）患者における 血液あるいは関節液中の諸成分の変動について は多くの研究がなされている1-4).また，これら 因子と臨床経過との関連についても，様々な研 究が行われている5-10). 一般に, RAの活動性を みる上で重要な指標となるのは，RA に特有の リウマチ因子 (以下 RF) の他に, 赤血球沈降速 度 (以下 ESR), C一反応性蛋白 (以下 CRP), $\beta_{2}$-マイクログロブリン (以下 $\beta_{2} \mathrm{MG}$ ), 免疫グ ロブリン等があげられている。しかし，慢性滕 関節障害における RA と変形性㮏関節症（以下 $O A)$ 患者の判別については充分検討されていな い.

本研究では, RA と OA 患者において, 男・ 女性及び女性について疾患別に血液と滕関節液 中の諸因子間の相関を求め，次いでこれらの因 子の測定值を用いて RA と OA の判別分析を 行い，両疾患の籃別上有効な測定因子は何かに ついての検討を行った。

\section{測定対象と方法}

1. 対象

岡山大学医学部附属病院及びその関連病院で, 膝関節液貯留を認め，ほほ同時に血液及び膝関 節液採取を行った RA 患者24例(男 5 例女19例, 平均年齢64.4 7 7.5歳）及U゙ $\mathrm{OA}$ 患者17例（男
5 例女 12 例, 平均年龄 $67.9 \pm 10.3$ 歳）を対象と した，患者血液を採取後，遠沈分離し得られた 血清（以下 S）と，関節液を採取後，約 2 分間 遠沈し得られた上清(以下 F) とを，直ちに約一 $30^{\circ} \mathrm{C}$ で凍結保存した。測定時に解凍し，解凍後 は速やかに次の方法により以下の諸因子の測定 を行った。

2. 方法

1) RF の測定

ラテックス凝集反応を用い, autoanalyzer(べ ーリングベルケ社製全自動免疫化学分析装置 ベーリングネフェロメータアナライザー）で測 定した，試薬は免疫化学自動分析用 LA 試薬 （LA-RF-II，栄研化学株式会社製）を用いた。 2) CRP の測定

抗七ト CRP 血清を用いる免疫比濁法により， autoanalyzer(前出)で測定した，試薬はC一反 応性蛋白測定用 CRP 免疫比渴用試薬（国際試 薬株式会社製）を用い，抗原抗体反応による混 濁度は340nmにおける吸光度より測定した。

3) $\beta_{2}$ MG の測定

ラテックス凝集反応を用い, autoanalyzer(前 出)で測定した。試薬は免疫化学自動分析用 LA 試薬(LA- $\beta_{2}$-マイクログロブリン，栄研化学株 式会社製）を用いた。

4) Lipid Peroxide (以下 LP) の測定

TBA 反応4)を用いる八木法 (监光法)により， 用手にて測定を行った. 試薬は過酸化脂質測定 
用キット(過酸化脂質ーテストワコー, 和光純 薬工業株式会社製）を用い，553nmにおける営 光強度より測定した。

5) ESR の測定

臨床検查法提要に従い，肘静脈より採血し Westergren 法で測定し， 1 時間値を使用した。

\section{結果}

RA とOA 患者（男・女性）について，血液 及び㮏関節夜中の測定因子の相互問の相関を調 べ, 更に判別分析を行って，以下の成績を得た。 男性の測定值の平均値と女性のそれとには $t$-test または Welch testで有意差が認められなかっ た（Table 1) ため，まず両性をまとめて処理 を行い，次いで大部分を占める女性については 別途に算出した。

1，男・女性の測定因子を用いた判別分析

1）RA と OA 間の血液と関節液中の各因子の 測定值における平均值差の検定

$\mathrm{RA}, \mathrm{OA}$ 患者の各因子の測定値の平均値, 不 偏標準偏差, 及U゙両患者の平均値の差異を $t$ 検 定又は Welchによる検定を行った（Table 2)。 S-RF 值では，RA とOA の患者間で，有意の

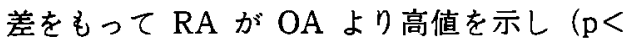
$0.05)$ ，また, $\operatorname{ESR}(\mathrm{p}<0.01), \mathrm{S}-\mathrm{CRP}(\mathrm{p}<0.05)$ ， $\mathrm{F}-\mathrm{CRP}(\mathrm{p}<0.01), \quad \mathrm{F}-\mathrm{RF}(\mathrm{p}<0.01), \mathrm{F}-\boldsymbol{\beta}_{2} \mathrm{MG}$ $(p<0.01)$ の測定値いずれも平均值間に有意に
Table 1 Test of difference in averages of mea sured values of determinants in RA and $O A$ patients between male and female

\begin{tabular}{|c|c|c|c|}
\hline \multirow{2}{*}{ Factors } & \multicolumn{2}{|c|}{ Mean $\pm \mathrm{SD}_{\mathrm{n}-1}$} & \multirow{2}{*}{$\begin{array}{c}t \text {-test or } \\
\text { Welch test }\end{array}$} \\
\hline & Male $n=5$ & Female $n=19$ & \\
\hline$(\mathrm{IU} / \mathrm{ml})$ & $250 \pm 399.8$ & $307.7 \pm 685.5$ & $t \mathrm{p}>0.05$ \\
\hline S-CRP $\quad(\mathrm{mg} / \mathrm{dl})$ & $3.93 \pm 3.84$ & $5.5 \pm 5.0$ & $t \mathrm{p}>0.05$ \\
\hline S-LP $(\mathrm{nmol} / \mathrm{ml})$ & $4.92 \pm 2.45$ & $7.0 \pm 3.6$ & $t \quad \mathrm{p}>0.05$ \\
\hline $\mathrm{S}-\beta_{2} \mathrm{MG}(\mu \mathrm{g} / \mathrm{ml})$ & $2.00 \pm 0.83$ & $2.2 \pm 1.0$ & $t \mathrm{p}>0.05$ \\
\hline$(\mathrm{IU} / \mathrm{ml})$ & $56.3 \pm 47.2$ & $182 \pm 205.5$ & $t \mathrm{p}>0.05$ \\
\hline F-CRP $\quad(\mathrm{mg} / \mathrm{dl})$ & $2.1 \pm 2.47$ & $2.19 \pm 2.73$ & $t \quad \mathrm{p}>0.05$ \\
\hline F-LP $(\mathrm{nmol} / \mathrm{ml})$ & $3.6 \pm 4.74$ & $2.4 \pm 1.07$ & $W p>0.05$ \\
\hline $\mathrm{F}-\beta_{2} \mathrm{MG}(\mu \mathrm{g} / \mathrm{ml})$ & $3.02 \pm 1.67$ & $3.69 \pm 1.47$ & $t \mathrm{p}>0.05$ \\
\hline $\operatorname{ESR} \quad(\mathrm{mm} / 1 \mathrm{hr})$ & $43.8 \pm 30.11$ & $65.63 \pm 30.48$ & $t \quad p>0.05$ \\
\hline age & $58.8 \pm 3.0$ & $65.68 \pm 7.81$ & \\
\hline
\end{tabular}

$\mathrm{OA}$

\begin{tabular}{|c|c|c|c|}
\hline \multirow{2}{*}{ Factors } & \multicolumn{2}{|c|}{ Mean $\pm S D_{n-1}$} & \multirow{2}{*}{$\begin{array}{c}t \text {-test or } \\
\text { Welch test }\end{array}$} \\
\hline & Male $n=5$ & Female $n=12$ & \\
\hline $\mathrm{S}-\mathrm{RF} \quad(\mathrm{IU} / \mathrm{ml})$ & $3.8 \pm 1.79$ & $4.25 \pm 2.38$ & $t \mathrm{p}>0.05$ \\
\hline $\mathrm{S}-\mathrm{CRP} \quad(\mathrm{mg} / \mathrm{dl})$ & $0.9 \pm 1.68$ & $2.36 \pm 4.11$ & $t \mathrm{p}>0.05$ \\
\hline $\mathrm{S}-\mathrm{LP} \quad(\mathrm{nmol} / \mathrm{ml})$ & $6.36 \pm 1.54$ & $5.29 \pm 2.19$ & $t \mathrm{p}>0.05$ \\
\hline $\mathrm{S}-\beta_{2} \mathrm{MG}(\mu \mathrm{g} / \mathrm{ml})$ & $1.52 \pm 0.40$ & $1.7 \pm 0.84$ & $t \mathrm{p}>0.05$ \\
\hline F-RF $\quad(\mathrm{IU} / \mathrm{ml})$ & $3.8 \pm 1.79$ & $3.0 \pm 0.0$ & $t \mathrm{p}>0.05$ \\
\hline F-CRP $\quad(\mathrm{mg} / \mathrm{dl})$ & $0.32 \pm 0.38$ & $0.44 \pm 1.00$ & $t \mathrm{p}>0.05$ \\
\hline $\mathrm{F}-\mathrm{LP} \quad(\mathrm{nmol} / \mathrm{ml})$ & $1.7 \pm 0.76$ & $1.98 \pm 1.72$ & $t \mathrm{p}>0.05$ \\
\hline $\mathrm{F}-\beta_{2} \mathrm{MG}(\mu \mathrm{g} / \mathrm{ml})$ & $2.26 \pm 0.51$ & $2.43 \pm 1.00$ & $t \mathrm{p}>0.05$ \\
\hline ESR (mm/1hr) & $13.8 \pm 8.35$ & $29.9 \pm 22.8$ & $W p>0.05$ \\
\hline age & $68.6 \pm 5.50$ & $67.92 \pm 11.83$ & \\
\hline
\end{tabular}

Table 2 Difference in mean value of measured factors of sera and synovial fluids between RA and OA

\begin{tabular}{|c|c|c|c|c|c|c|c|}
\hline & & & cases & & cases & & \\
\hline & tors & Mean & $\begin{array}{l}\text { Unbiased } \\
\text { Standard }\end{array}$ & Mean & $\begin{array}{l}\text { Unbiased } \\
\text { Standard }\end{array}$ & $\begin{array}{l}t \text {-test } \\
\text { Welch }\end{array}$ & $\begin{array}{l}\text { or } \\
\text { est }\end{array}$ \\
\hline S-RF & $(\mathrm{IU} / \mathrm{ml})$ & 286.6 & 632.4 & 17.0 & 52.9 & Welch & $*$ \\
\hline F-RF & $(\mathrm{IU} / \mathrm{ml})$ & 151.3 & 192.8 & 4.2 & 3.9 & $t$ & $* *$ \\
\hline $\mathrm{S}-\mathrm{CRP}$ & $(\mathrm{mg} / \mathrm{dl})$ & 5.2 & 4.7 & 1.9 & 3.6 & $t$ & $*$ \\
\hline $\mathrm{F}-\mathrm{CRP}$ & $(\mathrm{mg} / \mathrm{dl})$ & 2.2 & 2.6 & 0.4 & 0.8 & Welch & $* *$ \\
\hline S-LP & $(\mathrm{nmol} / \mathrm{ml})$ & 6.4 & 3.5 & 5.9 & 2.1 & Welch & - \\
\hline F-LP & $(\mathrm{nmol} / \mathrm{ml})$ & 2.2 & 1.1 & 1.9 & 1.5 & $t$ & - \\
\hline $\mathrm{S}-\beta_{2} \mathrm{MG}$ & $(\mu \mathrm{g} / \mathrm{ml})$ & 2.1 & 0.9 & 1.7 & 0.7 & $t$ & - \\
\hline $\mathrm{F}-\beta_{2} \mathrm{MG}$ & $(\mu \mathrm{g} / \mathrm{ml})$ & 3.5 & 1.5 & 2.4 & 0.9 & Welch & $* *$ \\
\hline ESR & $(\mathrm{mm} / 1 \mathrm{hr})$ & 60.4 & 32.1 & 26.1 & 20.4 & $t$ & $* *$ \\
\hline
\end{tabular}


RA が高值を示した。

2 ) 測定因子間の相関関係について

（1）血液と関節液中の因子測定値における相 関関係

$\mathrm{S}-\mathrm{F}$ 間の測定值の相関関係は Table $3 \mathrm{~A}$ と Bに示寸ごとくであるが、RA では $\mathrm{S}$ との测 定値の間に $\beta_{2} \mathrm{MG}(\mathrm{r}=0.889), \mathrm{CRP}(\mathrm{r}=0.884)$, LP $(r=0.596)$ ，の順に有意な相関関係 $(t$ 検定 により, $\mathrm{p}<0.05$ で母相関係数 $\rho=0$ を否定され る)が認められた. しかし，RFについてはS $\mathrm{F}$ の測定值間の相関関係は低功た（Table 3 A).一方, OAでは $\mathrm{S}$ と $\mathrm{F}$ の測定值間に $\mathrm{RF}(\mathrm{r}=$ 0.972), $\beta_{2} \mathrm{MG}(\mathrm{r}=0.877), \mathrm{CRP}(\mathrm{r}=0.856)$, $\mathrm{LP}(\mathrm{r}=0.417)$, の順に有意な相関関係が認めら れた (Table $3 \mathrm{~B}$ ).
(2) 血液因子測定値間の相関関係

$\mathrm{S}$ 中の各因子の測定值の相関関係は，RA で は CRP-ESR 間 $(\mathrm{r}=0.580), \mathrm{CRP}-\mathrm{RF}$ 間 $(\mathrm{r}=$ 0.535)，の順に有意な相関関係が認められた (Table $3 \mathrm{~A}$ )。一方, OA では CRP と ESR 間 $(r=0.689)$ に有意な相関関係が認められた. しかし， CRP とRF 間には有意な相関は認め られなかった (Table 3B).

(3) 関節液因子測定值間の相関関保

$\mathrm{F}$ 間の相関関係は，RAにおいては $\mathrm{F}$ 因子間 に有意な相関関係は認められなかった。一方, $\mathrm{OA}$ においてF中の CRP-LP 間 $(\mathrm{r}=0.689)$ にのみ有意な相関関係 $(\mathrm{p}<0.05)$ が認められた (Table $3 \mathrm{~B})$.

Table 3 A Correlation matrix between one paired sample among measured factors of sera and synovial fluids in rheumatoid arthritis (RA)

\begin{tabular}{|c|c|c|c|c|c|c|c|c|c|}
\hline & S-RF & S-CRP & S-LP & $\mathrm{S}-\beta_{2} \mathrm{MG}$ & $\mathrm{F}-\mathrm{RF}$ & $\mathrm{F}-\mathrm{CRP}$ & F-LP & $\mathrm{F}-\beta_{2} \mathrm{MG}$ & ESR \\
\hline S-RF & & $0.535^{* *}$ & -0.143 & 0.259 & 0.274 & $0.708^{* *}$ & 0.050 & 0.249 & 0.340 \\
\hline S-CRP & & & -0.290 & 0.148 & 0.206 & $0.844^{* *}$ & -0.064 & 0.190 & $0.580^{* *}$ \\
\hline S-LP & & & & -0.145 & -0.119 & -0.241 & $0.596^{* *}$ & -0.120 & 0.058 \\
\hline $\mathrm{S}-\beta_{2} \mathrm{MG}$ & & & & & 0.028 & 0.227 & -0.157 & $0.889^{* *}$ & 0.117 \\
\hline F-RF & & & & & & 0.108 & 0.273 & 0.080 & 0.177 \\
\hline F-CRP & & & & & & & -0.020 & 0.227 & $0.399^{*}$ \\
\hline F-LP & & & & & & & & 0.012 & 0.010 \\
\hline $\mathrm{F}-\beta_{2} \mathrm{MG}$ & & & & & & & & & 0.179 \\
\hline
\end{tabular}

Table $3 \mathrm{~B}$ Correlation matrix between one paired sample among measured factors of sera and synovial fluids in osteoarthritis $(\mathrm{OA})$

\begin{tabular}{|c|c|c|c|c|c|c|c|c|c|}
\hline & S-RF & S-CRP & S-LP & $\mathrm{S}-\boldsymbol{\beta}_{2} \mathrm{MG}$ & $\mathrm{F}-\mathrm{RF}$ & F-CRP & F-LP & $\mathrm{F}-\beta_{2} \mathrm{MG}$ & ESR \\
\hline S-RF & & -0.126 & 0.339 & 0.041 & $0.972^{* *}$ & -0.084 & -0.115 & -0.091 & -0.022 \\
\hline S-CRP & & & -0.073 & 0.231 & -0.158 & $0.856^{* *}$ & $0.610^{* *}$ & 0.286 & $0.689^{* *}$ \\
\hline S-LP & & & & -0.288 & 0.325 & 0.061 & $0.417^{*}$ & -0.318 & -0.032 \\
\hline $\mathrm{S}-\boldsymbol{\beta}_{2} \mathrm{MG}$ & & & & & 0.058 & -0.013 & -0.163 & $0.877^{* *}$ & 0.021 \\
\hline $\mathrm{F}-\mathrm{RF}$ & & & & & & -0.094 & -0.127 & -0.084 & -0.083 \\
\hline F-CRP & & & & & & & $0.689^{* *}$ & -0.025 & $0.744^{* *}$ \\
\hline F-LP & & & & & & & & 0.099 & $0.558^{*}$ \\
\hline $\mathrm{F}-\boldsymbol{\beta}_{2} \mathrm{MG}$ & & & & & & & & & -0.044 \\
\hline
\end{tabular}

$$
\begin{gathered}
\mathrm{n}=17 \text { Correlation coefficient of population : } p \neq 0 \\
t_{15}(5 \%)=0.404 \quad t_{15}(1 \%)=0.602 \quad *: \mathrm{p}<0.05 \quad * *: \mathrm{p}<0.01
\end{gathered}
$$


Table 4 Misclassification probability (M.C.P.) by discriminant analysis between RA and $O A$, using factors from both sexes (A) and that using factors from female (B)

A : Using factors from both sexes

\begin{tabular}{|c|c|c|c|}
\hline Parameter & M.C.P. & Parameter & M.C.P. \\
\hline ESR & $27.1 \%$ (1) & S-RF & $39.4 \%$ \\
\hline $\mathrm{F}-\mathrm{RF}$ & $31.2 \%$ (2) & S- $\beta_{2} \mathrm{MG}$ & $39.7 \%$ (7) \\
\hline $\mathrm{F}-\beta_{2} \mathrm{MG}$ & $33.4 \%$ (3) & F-LP & $45.2 \%$ (8) \\
\hline F-CRP & $33.7 \%$ (4) & S-LP & $46.8 \%$ (9) \\
\hline S-CRP & $35.2 \%$ (5) & & \\
\hline
\end{tabular}

* Symbols $(1) \sim(9)$ indicate the order of M.C.

$P$.

B : Using factors from female

\begin{tabular}{|c|c|c|c|}
\hline Parameter & M.C.P. & Parameter & M.C.P. \\
\hline ESR & $26.1 \%$ (1) & $\mathrm{S}-\beta_{2} \mathrm{MG}$ & $38.6 \%$ (6) \\
\hline $\mathrm{F}-\mathrm{RF}$ & $29.1 \%$ (2) & S-RF & $39.0 \%$ (7) \\
\hline $\mathrm{F}-\boldsymbol{\beta}_{2} \mathrm{MG}$ & $31.6 \%$ (3) & S-LP & $39.4 \%$ \\
\hline F-CRP & $34.8 \%$ (4) & F-LP & $45.2 \%$ (9) \\
\hline S-CRP & $36.7 \%$ (5) & & \\
\hline
\end{tabular}

\section{3 ) 判別分析}

単一因子による判別分析の成績は，ESR が最 も良好で $27.1 \%$ の誤判別確率を示し, 以下 $\mathrm{F}-$ $\mathrm{RF}, \mathrm{F}-\beta_{2} \mathrm{MG}$ と続いた. $\mathrm{S}$ と Fの比較では, $\mathrm{F}$ $-\mathrm{RF}$ (31.2\%) は S-RF（39.4\%）より判別誤
差が少なかった，F- $\beta_{2} \mathrm{MG}$ (33.4\%) は F-RF についで判別誤差が少なく，S- $\beta_{2} \mathrm{MG}$ (39.7\%) よりは比較的判別誤差が少ない，また $\mathrm{F}$ 間では F-CRP は F- $\beta_{2} \mathrm{MG}$ と大差なく, F-RF（31.2 $\%), F-\beta_{2} \mathrm{MG}(33.4 \%), \mathrm{F}-\mathrm{CRP}(33.7 \%) \sigma$ 順に判別誤差は少なかった (Table 4).

血液と関節液の 9 個の因子測定值を指標とし て用い，RA とOA 患者の判別分析を行った. RA とOA 患者判別の際，最良選択法を用いた 場合の最も有効な指標の組合せと各 step 別の誤 判別確率を見ると，3 指標まで各 stepに方たり 選出される指標は, ESR, F-RF, F- $\beta_{2} \mathrm{MG}$ て あった．また， 6 指標では18.4\%の誤判別確率 で判別が可能な事が認められた．その際の判別 の有効な指標としては, S-RF, F-RF, S-CRP, F-CRP， F- $\beta_{2} \mathrm{MG}$, ESR が選択された (Table $5 \mathrm{~A}-1$ ). 次いでRF は RA と OA 患者の判別 の際に RA 患者を決定する因子として用いられ ているので, S-RF，F-RF を削除した場合の残 存 7 因子を用いて判別を行った．その結果 3 指 標まででは，ESR，F- $\beta_{2} \mathrm{MG}$ ，S- $\beta_{2} \mathrm{MG}$ が指標 として選出され，その際の䛊判別確率は $23.0 \%$ を示した。また， 7 指標全部を用いた場合の愦 判別確率は $21.2 \%$ 示し， 9 指標の際の誤判別 確率17.1\%よりも高值であったが，比較的低い 誤差で判別可能である事が認められた(Table 5 B).

Table $5 \mathrm{~A}$ Effective indices selected by discriminant analysis using an all possible selection procedure (APSP) at successive steps with misclassification probability

- by the use of 9 factors (including S-RF and F-RF) -

A-1: Using factors from both sexes

\begin{tabular}{ccccccccccc}
\hline & S-RF & S-CRP & S-LP & S- $\beta_{2}$ MG & F-RF & F-CRP & F-LP & F- $\beta_{2}$ MG & ESR & M.C.P. \\
\hline STEP 1 & & & & & & & & & $*$ & $27.1 \%$ \\
STEP 2 & & & & & $*$ & & & & $*$ & $23.3 \%$ \\
STEP 3 & & & & & $*$ & & & $*$ & $*$ & $20.9 \%$ \\
STEP 4 & & & & $*$ & $*$ & & & $*$ & $*$ & $20.3 \%$ \\
STEP 5 & & & $*$ & $*$ & $*$ & & & $*$ & $*$ & $20.1 \%$ \\
STEP 6 & $*$ & $*$ & & & $*$ & $*$ & & $*$ & $*$ & $18.4 \%$ \\
STEP 7 & $*$ & $*$ & & $*$ & $*$ & $*$ & & $*$ & $*$ & $18.1 \%$ \\
STEP 8 & $*$ & $*$ & $*$ & & $*$ & $*$ & $*$ & $*$ & $*$ & $17.6 \%$ \\
STEP 9 & $*$ & $*$ & $*$ & $*$ & $*$ & $*$ & $*$ & $*$ & $*$ & $17.1 \%$ \\
\hline NFF $^{11}$ & 4 & 4 & 3 & 4 & 8 & 4 & 2 & 7 & 9 \\
\hline \multicolumn{7}{c}{ NF $^{1)}:$ Number of factors used to discriminant analysis by APSP }
\end{tabular}


A-2 : Using factors from female

\begin{tabular}{|c|c|c|c|c|c|c|c|c|c|c|}
\hline & S-RF & S-CRP & S-LP & $\mathrm{S}-\beta_{2} \mathrm{MG}$ & F-RF & F-CRP & F-LP & $\mathrm{F}-\beta_{2} \mathrm{MG}$ & ESR & M.C.P. \\
\hline STEP 1 & & & & & & & & & * & $26.1 \%$ \\
\hline STEP 2 & & & & & & & & $*$ & $*$ & $20.1 \%$ \\
\hline STEP 3 & & & & & * & & & * & * & $15.7 \%$ \\
\hline STEP 4 & & & $*$ & & $*$ & & & $*$ & $*$ & $12.5 \%$ \\
\hline STEP 5 & & & $*$ & $*$ & $*$ & & & $*$ & $*$ & $12.2 \%$ \\
\hline STEP 6 & & & $*$ & $*$ & $*$ & $*$ & & $*$ & $*$ & $11.4 \%$ \\
\hline STEP 7 & $*$ & $*$ & & $*$ & $*$ & $*$ & & $*$ & $*$ & $11.2 \%$ \\
\hline STEP 8 & * & * & $*$ & & * & $*$ & * & * & * & $10.7 \%$ \\
\hline STEP 9 & * & $*$ & $*$ & $*$ & $*$ & * & $*$ & $*$ & * & $10.4 \%$ \\
\hline $\mathrm{NF}^{1)}$ & 3 & 3 & 5 & 4 & 7 & 4 & 2 & 8 & 9 & \\
\hline
\end{tabular}

Table 5 B Effective indices selected by discriminant analysis using an all possible selection procedure (APSP) at successive steps with misclassification probability

- by the use of 7 factors (excluding S-RF and F-RF) -

\begin{tabular}{|c|c|c|c|c|c|c|c|c|}
\hline & S-CRP & S-LP & $\mathrm{S}-\beta_{2} \mathrm{MG}$ & F-CRP & F-LP & $\mathrm{F}-\beta_{2} \mathrm{MG}$ & ESR & M.C.P. \\
\hline STEP 1 & & & & & & & $*$ & $27.1 \%$ \\
\hline STEP 2 & & & & & & $*$ & * & $23.9 \%$ \\
\hline STEP 3 & & & * & & & * & * & $23.0 \%$ \\
\hline STEP 4 & $*$ & & & * & & $*$ & $*$ & $22.7 \%$ \\
\hline STEP 5 & * & & * & * & & * & $*$ & $21.8 \%$ \\
\hline STEP 6 & * & * & $*$ & * & & * & * & $21.5 \%$ \\
\hline STEP 7 & * & * & * & $*$ & $*$ & $*$ & * & $21.2 \%$ \\
\hline $\mathrm{NF}^{\prime \prime}$ & 4 & 2 & 4 & 4 & 1 & 6 & 7 & \\
\hline
\end{tabular}

APSP

\section{2.女性のみの測定因子を用いた判別分析}

本研究では RA，OA 患の因子測定值につい て，平均値の有意の差異が男女間に認められな いので両者を併せて算出したが，参考のため女 性のみで RA，OA の判別を行った，単一因子 を用いた際の哭判別確率では，1番目の ESRか ら 5 番目の S-CRP までの順序は両性の場合と 同じであり，かつ誤判別確率も近い值を示した (Table 4 B). また，最良選択法の STEP 別 の譟判別確率で 9 因子を用いた場合には, STEP 1，3，5，7では両性の場合と同じ因子の組 み合わせが選択され，STEP 2，4，6では差異
が認められた（Table 5A-2）。また，女性の みの测定值を用いた際の判別誤差は男女計より 明らかに少ない事が認められたすすなわち，男 女の因子測定值の平均値には有意差が認められ なくても，女性のみの測定値を用いた場合は因 子測定值が比較的均一であり，このことが判別 誤差を少なくしたと推定される.

\section{考察}

本研究では RA，OA 患者の因子湘定値につ いて，1）判別分析；a. 単一因子による判別, b. 最良選択法を用いた多因子による判別，2） 平均値差，3）相関，の検討を行った.

判別方程式については， $\mathrm{S}$ 及び $\mathrm{F}$ を用いた臨 床検査の結果より，数種のパラメーターの測定 値に重みづけをする事によって方程式を作成し， この方程式に RA か OA が疑われる患者のパ ラメーターを導入する事により，その疾患がい ずれに近いかまたは属するかを定める方法であ ク，多変量を用いた計量診断法である.

次いで判別方程式はデー夕数を決めた場合に， 最良選択法により判別に有効な指標を選ぶ事に より，どのような指標が両疾患の判別に有効で あるかを知る事ができる利点を有する。判別方 程式の疾患への応用については，古くは肝硬変 と胆道閉塞と肝炎について，ビリルビン量, 総 コレステリン量, コレステリン・エステル量, セファリン・コレステロール反応, 千モール混 濁反応，アルカリフォスファターゼ量などをパ 
ラメーターとしてこれらの疾患の判別を行った 報告 ${ }^{11)}$ がある．また，最近では血清酵素の測定 値をパラメーターとしての肝硬変と肝癌の判別 ${ }^{12)}$ の方程式の作成の他, maximal expiratory flow-volume curveより得られた測定指標によ る正常人と喘息患者の判別 $\left.{ }^{13}\right)$ などの報告がある. しかし，RAとOA 患者についての判別分析の 試行例は現在までみられない.

有効指標数と誤判別確率については，誤判別 確率はパラメーターに RF を用いた場合，1指 標では27.1\%，3 指標では $20.9 \% ， 5$ 指標では $20.1 \% ， 7$ 指標では $18.1 \% ， 9$ 指標では $17.1 \%$ であり， 3 指標と 5 指標の間， 6 指標と 7 指標 の間, 8 指標と 9 指標の間には誤判別確率に大 差ない.一応 6 指標（䛊判別確率18.4\%）では 判別の目的を達成できると考えられる。これは 健康人と全喘息患者の 9 指標での誤判別確率 $15.5 \%{ }^{13)}$ に比へててやや多い值と考えられる。一 方パラメーターに RF を用いなかった場合にも， 1 指標では27.1\%であり，全指標である 7 指標 では $21.2 \%$ と，譟判別確率はやや高い值を示し た.

測定因子の病態における意義と，判別に对す る奇与度, 血液・関節液の因子測定值の相関に ついては，RA と OA の判別分析に用いられた パラメーター（特にパラメーターの数を限局し たときの有効指標）は，病態上あるいは臨床上 の関連が高いと考えられる.

現在までにおける RA の診断法として，RF については以下の検查法上, 特異的診断法とし て最も重要視きれている. 即ち, 赤血球に変性

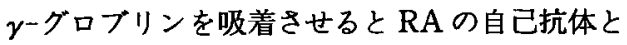
の反応が起こる現象が発見 ${ }^{14)}$ されて以来, $\mathrm{RF}$ 湘 定法に種々の改良が加えられ，その結果として RF はRAの患者の診断法として確立され，広 く用いられている.ささらに RFの簡便な測定法 としては, Singer \& Plotzによるラテックス粒 子凝集免疫測定法 ${ }^{15)}$ の開発により, 今日も広く 用いられている。 また，RA 患者の血清の RF 測定の他に，関節液中の測定についても多くの 報告がある，RA 患者の血清, 関節液の蛋白に ついて, Seno ${ }^{16)}$ は RA 患者ではゲル滤過法に よる19Sを含む第 1 ピークの蛋白比（13.0\%）
が OA 患者のそれ (8.4\%) より高く，RA 患 者の血清で仙第 1 ピークの蛋白比 (21.2\%) は 正常人のそれ (11.6\%) より高值を示すとして いる.さらに, Waaler-Rose test (SSCA).及 び LFT は第 1 ピークにのみ認められると述べ ている. 本研究の判別分析では, 関節液の RF 測 定值は血清の RF 测定値と共に判別の際に有用 であった。これは S-RF 值の上昇が RA の診 断基準の 1 項目として用いられている事からも 当然と考えられる。

また，ESR は過去において急性炎症の指標と して用いられるばかりでなく，慢性炎症を呈す 結核の進行度の評価などに用いられてきたが, 現在では RAの病勢の指標としても用いられて いる. 判別分析では，ESR は最も判別に有用で あったが，RA 患者では慢性炎症の為だけでな く，貧血の為に ESR が充進するとされており 注意を要する。

CRP, $\beta_{2} \mathrm{MG}, \mathrm{LP}$ は, RA の補助診断法とし て用いられている. RA と OAの判別における これら因子の病理的意義についてはいくつかの 問題がある。

CRP については, Farr ら ${ }^{5)}$ がS と Fの測定 値間に相関があるとし，測定値と局所症状の強 さの関係についても報告した，Rowe らの)は S CRP と F-CRP との間に密接な相関関係 $(\mathrm{r}=$ 0.74）があり，RA では S-CRP が F-CRP よ ク高值であり，F/S 比は $30 \%$ と報告している。 また, Walter ら"も CRP の值については S$\mathrm{CRP}$ が F-CRP より高值で，F/S 比も約 $60 \%$ とRowe $\mathrm{e}^{6)}$ よりもやや高值であることを報告し ている.本研究における RAの成績では, F-CRP と S-CRP の相関関係は $\mathrm{r}=0.84$ と良い相関を 示し (Spearman で相関係数の值は0.43)，SCRP でF-CRP の代用が可能であると考之られ た。また，F/S 比は $42 \%$ の値を示し Walter ら ${ }^{7)}$ よりは低值であったが, Rowe ら゙)よりは高值 であった (OA では20\%).また，Rowe らのは 正常人においてその $\mathrm{F} / \mathrm{S}$ 比は各種血清蛋白の分 子量と正の比例関係にある事を報告したが，同 時に RA の CRP では分子量に比へて $\mathrm{F} / \mathrm{S}$ 比が 低いことから，CRPは滑膜に選択的に結合する か滑膜で特に消費され，RAの炎症機構に大切 
な役割をもっている事を示唆している.Farr ら は RA では S-CRP，F-CRPが，OAにおける よりも高値であると述へてている，また，局所症 状に score をつけることにより疾患活動性を調 べ, 疾患活動性と血液と関節液の多くの検查值 の相関関係を調べた結果, RA の局所症状の程 度 (発熱, 発赤, 圧痛) は, 関節液中の多核白 血球数の増加 (リンパ球の減少), グルコースの 减少, S-CRP の増加等と相関関係を示した。ま た,これらの因子は局所症状をより反映してい ると報告している.

$\beta_{2}$ MG については, Walter ら”がいうよう にFの測定值がSのそれよりも高く(約150\%), また測定值間に Spearman の相関係数は 0.5 を 示した.このことより, F- $\beta_{2} \mathrm{MG}$ と S- $\beta_{2} \mathrm{MG} の$ 間に良い相関関係があるものと考えられる。本 研究の成績では，F值は S 值の約 $167 \%$ であり， 相関係数も 0.889 と, 同様の傾向を示した. HLA の light chain である $\beta_{2} \mathrm{MG}$ の增加については, B細胞または丁細胞から産生されると言われて

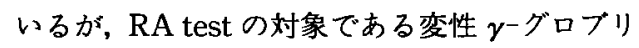
ン (IgG) と反応する自己抗体は IgMであり，

$\mathrm{B}$ 細胞より産生されると言われている。従って $\beta_{2} \mathrm{MG}$ の增加は膠原病特に自己免疫疾患と関係 が比較的高く， RA の診断においては RFにつ いで特異性があると考えられる。

Manicourt ら”は，RA 患者の50\%において 血清 $\beta_{2} \mathrm{MG}$ が正常值を越えており，関節症状の 重症度のパラメーターと考えられると述へてい る. 一方, Sjöblom ら ${ }^{2)}$ は RA 患者の33\%にお いて $\beta_{2} \mathrm{MG}$ の上昇を認めると報告している. Ström ら ${ }^{3)}$ は, RA 患者50例において $\beta_{2} \mathrm{MG}$ と ESR が有意に相関するとしている $(r=0.41)$. Crisp ら ${ }^{8)}$ は， 6 力月間の auranofin 投与で治 療すると $\beta_{2} \mathrm{MG}$ レベルが有意に低下し，また CRP も低下したと述へた.38例中26例では $\beta_{2} \mathrm{MG} か ゙$ 正常化し,この結果から血清 $\beta_{2} \mathrm{MG}$ レベルは疾 患活動性をよく反映していると述べた。一方, Mallya ら 9 は S-CRP 濃度が RA の病勢を密 接に表し，また ESR は CRP に引き続いてえ 進するが, 病勢の程度との相関については, CRP は ESRよりも強い相関があるとしている.Dixon ら ${ }^{10)}$ は RA 患者を種々の抗リウマチ薬で治療
した時の CRP による治療効果の判定は，ハプ トグロビン, フィブリノーゲン, ESR よりも有 効であると述べている。従って RA 自体の病勢 や治療効果の判定には, $\beta_{2} \mathrm{MG}, \mathrm{CRP}$ が ESR 上 りも有効であるといえる。しかし，本研究で行 つた判別分析においては単一指標のみの場合に は ESR, F-RF, F- $\boldsymbol{\beta}_{2} \mathrm{MG}, \mathrm{F}-\mathrm{CRP}$ の順に判別 愦差が少なく，この点について今後さらに検討 を行う必要があると考えられた。

LPについて，Rawley ら4は LP の測定に TBA 反応を用い, 反応物質が RA の S と Fに おいて見いだきれ，さらに TBA 反応值が関節 液の鉄イオン濃度との間に相関関係 $(\mathrm{r}=0.78)$ がある事を示した。 また，同時に F-CRP と F の TBA 反応物質との間に良い相関関係がある と述べた。本研究では, RA では $\mathrm{OA} よ り$ LP 値, S-LP值ともに高値を示したが, 両者の 間の相関関係は OA にのみ認められた。

$\mathrm{S}$ と Fの測定因子の相関については RA, OA 共に $\mathrm{S}$ と F の測定值の間に $\beta_{2} \mathrm{MG}, \mathrm{CRP}, \mathrm{LP}$ に 有意な相関関係を認め，これら相関関係の高い 因子については，Sの測定值から Fのそれを推 定することが可能であると考えられた.

尚, 本研究においては RA, OA の因子測定 値の有意差について男女間に差異が認められな かったので，両性を併せて判別を行ったが，比 較的多数を占める女性のみで算出した成績は 9 因子で10.4\%であり，両性のものよりも明らか に判別誤差が少なかった，女性のみを用いた方 が，男女計よりも集団としての均一性が保たれ ていると推察された。

\section{結論}

RA とOAの患者について S，F中の測定因 子の相互間の相関関係の検討及び判別分析を行 い，以下の成績を得た。

1. $\mathrm{RA}$ と $\mathrm{OA}$ 患者間の $\mathrm{S}$ と $\mathrm{F}$ 中測定值の平 均值差の検定では, S-RF, F-RF, S-CRP, F -CRP, F- $\boldsymbol{\beta}_{2} \mathrm{MG}, \mathrm{ESR}$ はいずれも両疾患の測 定值の平均値に有意な差を示し， RA において 高值であった。

2．血液と関節液測定値の相関関係では, RA は $\beta_{2} \mathrm{MG}(\mathrm{r}=0.889), \mathrm{CRP}(\mathrm{r}=0.884), \mathrm{LP}(\mathrm{r}=$ 
0.596)の順に S と Fの測定値の間に有意な相関 関係が認められ, RF では相関関係は低かった。 また, OA では RF ( $\mathrm{r}=0.972), \beta_{2} \mathrm{MG}(\mathrm{r}=$ $0.877), \operatorname{CRP}(\mathrm{r}=0.856), \operatorname{LP}(\mathrm{r}=0.417), の$ 順に両測定値の間に有意な相関関係が認められ た.

3. 血液測定値間の相関関俰では，RA は CRP-ESR 間 $(r=0.580), C R P-R F$ 間 $(r=$ 0.535），の順に有意な相関関係が認められた。 また，OA ではCRP-ESR 間 $(r=0.689)$ に有 意な相関関係が認められた. CRP-RF 間には有 意な相関関係は認められなかった。

4. 関節液測定値間の相関関係は，OA にお いて CRP と LP 間 $(r=0.689)$ にのみ有意な 相関関係が認められた。

5 . 単一因子を用いる判別誤差の成績は, ESR, F-RF, F- $\beta_{2}$ MG, F-CRP, S-RF, S- $\beta_{2}$ $\mathrm{MG}$ の順に判別誤差が少なく, RA と OAの湘 定值の平均值の差の検定とほぼ一致した.

6. S と Fの各因子測定值を指標として, RA
患者とOA 患者の最良選択法による判別分析を 行った結果， 9 指標中 6 指標を用いた場合 18.4 \%の誤判別確率で判別が可能な事が認められた。 また，その判別の有効な 6 指標として血清の RF， $\mathrm{CRP}$, 血沈, 関節液の $\mathrm{RF}, \mathrm{CRP}, \beta_{2} \mathrm{MG}$ が選 択された. $\mathrm{S}$ 及び $\mathrm{F}$ 中の RF を因子より削除し， 残り 7 指標全てを用いて判別を行った場合には 誤判別確率は $21.2 \%$ を示した。

7. 女性のみの測定值を用いた際の判別誤差 は，男女計のものより成績が良かった。

稿を終えるにあたり御的切な研究の御指導と論文 の御校閲を賜った岡山大学医学部整形外科学教室井 上一教授に对し厚く御礼申し上げます。また判別 分析について御指導を戴いた現近畿大学医学部衛生 学教室目黒忠道教授に厚く御礼申し上げます。また 論文の作成に御教示を戴いた岡山大学整形外科学教 室横山良樹先生，試料の収集に御助力を戴いた倉敷 広済病院江沢英光院長, 落合病院井口昌害院長に謝 意を表します。

\section{女}

\section{献}

1) Manicourt $D$, Brauman $H$ and Orloff $S$ : Plasma and urinary levels of $\beta_{2}$-microglobulin in rheumatoid arthritis. Ann Rheum Dis (1978) 37, 328-332.

2) Sjöblom KG, Saxne T and Wollheim FA : Plasma levels of $\beta_{2}$-microglobulin in rheumatoid arthritis. Ann Rheum Dis (1980) 39, 333-339.

3) Ström $T$ and Evrin PE : Beta 2 microglobulin in RA. Ann Rheum Dis (1981) 40, 211-213.

4) Rowley D, Gutteridge JMC, Blake D, Farr M and Halliwell B : Lipid peroxidation in rheumatoid arthritis : thiobarbituric and catalytc iron salts in synovial fluid from rheumatoid patients. Clin Sci (1984) 66, 691-695.

5) Farr M, Kendall MJ, Young DW, Meynell MJ and Hawkins CF : Assessment of rheumatoid activity based on clinical features and blood and synovial fluid analysis. Ann Rheum Dis (1976) 35, 163167.

6) Rowe IF, Sheldon J, Riches PG and Keat ACS : Comparative studies of the serum and synovial fluid C reactive protein concentrations. Ann Rheum Dis (1987) 46, 721-726.

7) Walters MT, Stevenson FK, Goswami R, Smith JL and Cawley MID : Comparison of the serum and synovial fluid concentrations of $\beta_{2}$-microglobulin and $\mathrm{C}$-reactive protein in relation to clinical disease activity and synovial inflamation in rheumatoid arthritis. Ann Rheum Dis (1989) 48, 905911.

8) Crisp A, Coughlan R, Mackintosh D, Clark B and Panayi G : $\beta_{2}$-microglobulin plasma levels reflect disease activity in rheumatoid arthritis. J Rheumatol (1983) 10, 954-956.

9) Mallya RK, Beer FC, Berry H, Hamilton EDB, Mace BEW and Pepys MB : Correlation of clinical 
parameters of disease activity in rheumatoid arthritis with serum concentration of $\mathrm{C}$-reactive protein and erythrocyte sedimentation rate. J Rheumatol (1982) 9, 224-228.

10) Dixon JS, Bird HA, Sitton NG, Pickup ME and Wright V:C-reactive protein in the serial assessment of disease activity in rheumatoid arthritis. Scand J Rheumatol (1984) 13, 39-44.

11）鳥居敏雄，高橋 正, 土肥一郎：判別函数；医学·生物学のための推計学, 東京大学出版会, 東京 (1965) pp 73-85.

12）広田 滋：電子計算機による肝疾患診断方式の研究一第 1 編一次関数による肝疾患診断一。肝縢 (1967) $8,130-140$.

13) Meguro $T$ and Ogata $M$ : Discriminant analysis of asthmatic patients and healthy adults using maximal expiratory indices - Selection of effective maximal expiratory indices 一. 周山医誌 (1988) 101, $175-187$.

14) Heller G, Jacobson AS and Kolody MH : A modification of the hemagglutination test for rheumatoid arthritis. Proc Soc Exp Biol Med (1949) 72, 316-323.

15) Plotz $\mathrm{CM}$ and Singer JM: The latex fixation test. I. Application to serologic diagnosis of rheumatoid arthritis, II. Result in rheumateid arthritis. Am J Med (1956) 21, 888-892.

16) Seno $T$ : Protein concentration of synovial fluid in Chronic Rheumatoid Arthritis. Estimation of protein in the synovial fluid of chronic rheumatoid arthritis by gel filtration and paper erectrophoresis. Acta Med Okayama (1968) 22, 51-58. 


\section{Discriminant analysis and comparison between rheumatoid arthritis and osteoarthritis after measurement of determinants in the blood and synovial fluid Kazuo Munetomo Department of Orthopaedic Surgery, Okayama University Medical School, Okayama 700, Japan \\ (Director : Prof. H. Inoue)}

Levels of rheumatoid factor(RF), $\beta_{2}$-microglobulin $\left(\beta_{2} M G\right)$, C-reactive protein(CRP) and lipid peroxide(LP) in the blood and synovial fluid(SF) and erythrocyte sedimentation rate (ESR) of patients with rheumatoid arthritis(RA) and osteoarthritis(OA) were determined by clinical chemistry. These determinants were analyzed to discriminate RA and $O A$.

Differences in the average values of determinants in the blood and SF between RA and OA patients were calculated. Significant differences in the values of ESR, S-CRP, F-CRP and $\beta_{2}$ MG between the two groups were observed.

In a discriminant analysis of $\mathrm{RA}$ and $\mathrm{OA}$ patients by an all possible selection procedure(APSP), nine parameters in blood and SF were used. In the analysis, S-RF, S-CRP, F-RF, F-CRP, F- $\beta_{2} M G$ and ESR were selected as the group of the 6 most effective indices, which gave an $18.4 \%$ probability of misclassification. When S-RF and F-RF were excluded, and only $\mathbf{7}$ factors were used for discriminant analysis, the probability of misclassification was 21.2\%. Probability of misclassification using measured values with females was less than that using males and females. 